\title{
Analysis of Communication Networks among Political Elites in the Formation of Party Coalitions
}

\author{
Intan Ferazia ${ }^{1}$, Prayudi ${ }^{2}$, Subhan Afifi ${ }^{3}$ \\ 1,2,3 Department of Communication Science, Faculty of Social and Political Science \\ Universitas Pembangunan Nasional "Veteran" Yogyakarta \\ Jl. Babarsari 2, Tambakbayan, Yogyakarta 55281, Indonesia \\ Email: prayudi@upnyk.ac.id ${ }^{2 *}$; subhanafifi@yahoo.com ${ }^{3}$ \\ *Corresponding author
}

\begin{abstract}
The multi-party system and the limitations of the presidential threshold adopted by Indonesian democracy have encouraged political parties to coalesce with each other. This study aims to analyze communication networks and the special role of political elites in the formation of party coalitions in the 2019 Presidential Election in Indonesia. This research method adopts a communication network analysis to identify the structure of the communication network between political elites and the roles they play in relation to the formation of party coalitions for the 2019 Presidential Election. The findings indicated that the formation of party coalitions was not only due to the ideological similarities. It was also based on the existence of political profit and loss considerations in a coalition, both in targeting positions and targeting support to win the Presidential Election. Further, the experience of political actors in building relations also played an important role. The contribution of this research is in the form of recommendations for new methods of communication networks.

Keywords: Communication Network; Political Communication; Political Elites; Presidential Election

Abstrak

Sistem multipartai dan keterbatasan ambang batas presidensial yang dianut demokrasi Indonesia mendorong parpol untuk bersatu padu. Penelitian ini bertujuan untuk menganalisis jaringan komunikasi dan peran khusus para elit politik dalam pembentukan koalisi partai pada Pilpres 2019 di Indonesia. Metode penelitian ini mengadopsi analisis jaringan komunikasi untuk mengidentifikasi struktur jaringan komunikasi antar elit politik dan peran yang mereka mainkan terkait pembentukan koalisi partai untuk Pilpres 2019. Hasil temuan menunjukkan bahwa pembentukan koalisi partai bukan hanya karena kesamaan ideologis. Hal itu juga didasarkan pada adanya pertimbangan untung rugi politik dalam koalisi, baik dalam mengincar posisi maupun mengincar dukungan untuk memenangkan Pilpres. Lebih lanjut, pengalaman para aktor politik dalam membangun relasi juga memegang peranan penting. Kontribusi penelitian ini berupa rekomendasi metode baru berupa jaringan komunikasi.
\end{abstract}

Kata kunci: Jaringan Komunikasi; Komunikasi Politik; Elit Politik; Pemilu Presiden

\section{Introduction}

Politics refers to a series of activities associated with the governance of a country or an area. It incorporates making decisions that apply to members of a group (Hague, Harrop, \& McCormick, 2016). A political party is a way to reach a political goal. In modern nation-states, as Satori said, "people have formed political parties to represent their ideas. They agree to take the same position on many issues and agree to support the same changes to law and the same leaders" (2005, p. 53). This political party becomes a political vehicle that will participate in general elections (Cangara, 2009).
Politics and the media are in an interconnectedness relationship. As a significant political event that takes place every five years, the general election and its process become media attention. The role of mass media is significant as political elites who interact with each other, negotiate and lobby will also compete to get support and sympathy from the public; and mass media is the right instrument. These political communication activities, reported by news media, create a communication network.

Politic and communication in Indonesia have become the research focus of many scholars. Some focus on woman political communication 
roles (Adeni \& Harahap, 2018; Ainiyah, 2017; Roqib, 2008; Sulaiman, 2010), while others focus on media coverage of the general election and political perception (Evelina \& Angeline, 2015; Sambrook \& Cushion, 2015; Tiyanto, Pawito, Nilan, \& Hastjarjo, 2008).

For example, research by Adeni dan Harahap (2018) is describing the general picture of women and communication in the political or legislative arena in Indonesia. Communication and the role of women have not been significant in the political or legislative scene. Male dominance becomes an inseparable part because of the strongly embedded culture of patriarchy in Indonesia. But women do not stop fighting for her voice. Dedication of women seen in some areas by making women as leaders. It shows women's progress and her desire to move forward and can be a representation of other women's aspirations.

A study titled Upaya Mengatasi Golput pada Pemilu 2014 by Evelina and Angeline (2015) is one of the example researches that focus on media coverage of the general election and political perception. This study aims to find the 2014 election socialization efforts of the General Election Commission to reduce the level of abstentions and how the media shape public opinion to reduce the absentees. The results mentioned that the commission and the media have not been systematically designing programs that can persuade the public to participate in the election of 2014 .

Other research on political communication in the general election was conducted by Pujono, Muktiyo, and Hastjarjo (2015). The results of this general research show that victory in the election competition is not solely based on financial capacity, but on the existence of social, economic, cultural, and religious interactions in society. This causes participants to become known, have a personal image, and have a degree of acceptance in society.
To date, it is difficult to find research that focuses on the communication network among political elites. Further, it is quite rare to picture communication network through media portrayals of the interaction among political elites. For a country that adheres to a democratic governance system, political parties become a means of democracy which acts as a liaison between the people and the government. Through these political parties, people have the right to determine who will be their representatives and who will determine the next general policy. General elections are activities that are common in democratic countries like Indonesia.

The multi-party system adopted in Indonesia requires these parties to form coalitions. The need for coalition formation is because the votes given by citizens in general elections are divided into various parties, making it difficult to determine the majority vote. This condition is called the Presidential Threshold (PT). The parliamentary threshold is the minimum vote limit of political parties in general elections to participate in determining the acquisition of seats in the DPR. This parliamentary threshold was made to stabilize relations between the Executive and Legislature in a democratic country (Julianda, 2018; Strata, 2016). PT 20-25 percent in the Election Law means that political parties or a combination of political parties that can carry the presidential candidate are those who get $20 \%$ of seats in the House of Representatives (Dewan Perwakilan Rakyat or DPR) or $25 \%$ of the national votes in the 2014 election.

In the 2009 election, three presidential candidates tried to fight for power. The SBYBoediono pair was carried out by 23 coalition parties, nine political parties carried the Mega-Prabowo pair, and only two parties carried the Jusuf Kalla-Wiranto pair. The final results of the 2009 presidential election crowned the SBY pair for the presidency for two periods. Based on these facts, the number 
of political parties that formed coalitions to support presidential candidates was able to produce victory in the 2004 and 2009 elections.

However, a different case occurred in the 2014 election. According to Indonesian law, only parties or coalitions controlling $20 \%$ of $D P R$ seats or winning $25 \%$ of the favorite votes in the parliamentary elections were eligible to nominate a candidate. Since there was no party exceeded the threshold in the 2014 legislative elections, political parties formed two coalitions- Gerindra, Golkar, PPP, PKS, PAN, or Demokrat (63.04\% of DPR seats) and PDI-P, Hanura, NasDem, or PKB (36.96\% DPR seats) (Prokurat, 2014). Two couples ran for president and vice president including Prabowo-Hatta and Jokowi-Jusuf Kalla. Six political parties joined in supporting Prabowo-Hatta and four other political parties supporting Jokowi-Jusuf Kalla. The 2014 general election finally declared Jokowi-Jusuf Kalla as the elected president and vice president even though only four political parties supported the pair. Thus, politics in Indonesia is very dynamic.

Within the context of forming a coalition to reach the political goal, communication among political elites plays a vital role. According to Mulyana (2013, p. 10), "political communication in Indonesia is more suitable if conceptualized as political communication that is dynamic, volatile, complicated and difficult to predict." The 2019 election was a political agenda awaited by the Indonesian people as it dealt with two political issues that determine the fate of the nation in the next five years. First was in order to elect people's representatives who will sit in the legislature. The second was to directly elect presidential and vice presidential figures who were worthy of leading a pluralistic nation in terms of SARA.

In the process of preparing for the Presidential Election held on 17 April 2019, each party had considered going to a coalition with which party to carry out their respective candidates. Political elites must go through the process of political communication to reach a coalition agreement. In political communication, some political actors act as communicants who try to negotiate with other actors who act as communicators in order to reach an agreement.

Thus, an analysis of how the formation of a communication network between and among political elites in an attempt to win the election is essential to examine. Information exchange occurs when these political elites interact with each other in order to win the 2019 Presidential Election. It is this exchange of information that will form a communication network. Through communication network analysis, popular political parties or selected political actors will emerge. For example, political actor A from party 1 communicates with political actor B from party 2 to coalition in carrying out particular presidential and vice presidential candidate pairs. Meanwhile, political actor $\mathrm{C}$ from party 3 prefers to communicate with political actors $\mathrm{D}$ from party 4 to coalition to carry out other pairs and so on.

\section{Political Communication}

Political communication is communication that involves political messages and political actors or is related to power, government, and government policies. It is the ways and intentions of message senders to influence the political environment. This includes public discussion (e.g., political speeches, news media coverage, and ordinary citizens' talk) that considers who has authority to sanction, the allocation of public resources, who has authority to make a decision, as well as social meaning like what makes someone American. In their words "the crucial factor that makes communication 'political' is not the source of a message, but its content and purpose." (Denton \& Woodward, 1998). McNair offers a similar definition when he writes that political communication is "purposeful communication about politics." It means that this covers not only verbal or written 
statements, but also visual representations such as dress, make-up, hairstyle or logo design (McNair, 2017). Communication politics is very necessary in activity political (Wahid, 2012).

Political communicators are people who communicate about politics, from chat in coffee shops toparliamentary sessions to discuss political issues such as the state constitution. Political communicators consist of three categories: politicians, professionals, and activists. However, the primary communicators are political elites or government officials as they are the ones who actively create political messages for their political interests (Nimmo, 2019). The primary political communicators play a significant social role, especially in the process of public opinion.

\section{Communication Network}

Networks are social structures created by communication among individuals and groups (Monge \& Contractor, 2003). Rogers and Kincaid (1981) define communication networks as "a network of interconnected individuals connected by patterned communication flows". Contacts and links occur as people communicate with others, (Littlejohn \& Foss, 2010). The link is a communication path within an organization (Jaubah, 2013). An individual always plays a role in creating networks that develop through daily activities and then relationships will be created through continuous communication between these individuals.

The basic structural idea of network theory is the connectedness - the idea that there is a reasonably solid communication pattern between individuals. Individuals who communicate also connect in groups which are then connected to the entire network. Everyone has a special relationship with other people in the organization. The communication network is a channel used to forward messages from one person to another. This network is seen from two perspectives, namely: 1) small groups according to the resources it has to develop communication patterns combine several communication network structures; 2) communication network as the formalized structure created by the organization as a means of organizational communication (JK, 2017).

Network analysis can explain various functions that can be fulfilled by the same link in a network, such as meetings, information sharing, or influence. This networking aspect is called multiplexity. Also, according to network theory, an organization is a link between two people who can define a specific role for a network, which means that they connect groups in specific ways. For example, an individual acts as a bridge that connects a group to another group in a network and he is a member of a group that is also a member of another group. Then there is an individual called liaison, he connects two groups, but is not a member of the group. There is also an individual called isolate; he is an individual who does not connect to any group (Littlejohn \& Foss, 2010).

In a network, we can also see the degree that connects someone with other people. The in-degree indicates the number of contacts a person makes with other people, while the outdegree is the number of links a person uses with other people. Centrality is the level at which a person connects with other people. This analysis also looks at the quality of the links between individuals. For example, there are direct links. This means that a straight link connects two people directly. There are also indirect links where there are two people who connect one another through a third person (Monge \& Contractor, 2003).

\section{Party Coalition}

The coalition theory literature is conceptually diverse, and many of the more significant models within the genre are to some extent contradictory. Drawing upon formal theories of politics, much of the early modeling relied upon a strictly game-theoretical approach, and the majority of it took an "office-seeking" perspective that either ignored or down-graded the policy dimension as a formation criterion (Lees, 2010). 
Following this understanding, Cheibub (2007) explains that the two characters influence the coalition model. The first character, namely the effort to pursue office seeking positions, where party behavior in building coalitions is based more on the desire to increase opportunities in obtaining positions in the government cabinet. So that in choosing coalition partners, political elites tend to be driven by the desire to maximize the negotiation process in power-sharing. That is why the party's internal maneuvers appear to be close to candidates who have the potential to win the election.

The second character is vote seeking mode, where elite political parties form coalitions based on efforts to win elections. The mode to win is what makes the party open to anyone who wants to join (catch-all), provided that victory in the general election is achievable. In the catchall logic, there is no reason for the party to reject coalition partners who want to join forces to defeat competitors. In this context, ideological distance is not significant. The most vital thing is to win the fight. That is why, in the logic of vote-seeking, a paradox will emerge in the process of forming a coalition, where parties that have a vast ideological distance can meet.
Based on the explanation above, this study aims to analyze communication networks and the special role of political elites in the formation of party coalitions in the 2019 Presidential Election in Indonesia.

\section{Research Methods}

Communication network research stresses actors and unique relationships or exchanges of messages. Communication networks analysis is a research method to identify the structure of communicationina system, where the relationship data regarding the flow of communication is analyzed using several types of interpersonal relationships as a unit of analysis. The network is a specific type of connection that connects a group of people or objects, where people or the object applies as an actor (node) from a network (Setiawan \& Siregar, 1987; Wasserman, Urbana-Champaign), \& Faust, 1994). Communication network analysis is a research approach that studies human behavior through convergence models. The unit of analysis is the communication relationship between two or more individuals in the system (communication network, clicks, and the whole system).

Table 1 Indicators of specific roles in the network

\begin{tabular}{ll}
\hline \multicolumn{1}{c}{ Dimension } & \multicolumn{1}{c}{ Indicators } \\
\hline Click & - Part of a communication network system \\
& - Most often communicate with other members (familiar) \\
Bridge/Cutpoints & - The connector between one click and another \\
Star/Hubs & - is a member of the click \\
& - The most chosen individuals in a system \\
& - Someone who is the center of communication from \\
& several people \\
Cosmopolites & - Networked individuals who can relate to the relative of \\
& all actors in the system. \\
& - Closest to other actors in the network \\
Isolate & - Not selected and not chosen \\
& - Closed individuals \\
& - Not any click member
\end{tabular}

Source: Author's personal research (2019) 
This research analyzes the communication network among political elites in the formation of party coalitions in the 2019 presidential election through the portrayal of interaction among political elites in news media. In a communication network, there are particular roles played by specific individuals. Individual roles in communication networks are as follow:

The primary data source in this study were text data written in the main report of Tempo News Magazine. The edition included from 8-14 January 2018 edition until the July 9-15 July 2018 edition of the party coalition in the face of the 2019 Presidential Election. In total, there were 14 news items to be analysed.

\section{Result of Research And Discussion Process of Forming Party Coalition}

The dynamics of the formation process of party coalition in the 2019 presidential election anchored in the formation of two presidential candidates: Jokowi and Prabowo Subianto. The two presidential candidates who competed in the 2019 Presidential Election were the same as the Presidential candidates in the 2014 Presidential Election. In other words, this 2019 election was a 2014 election rematch. The difference lied in political parties that supported both candidates in the 2019 election. The following is a map of the distribution of party coalitions in the 2019 Presidential Election:

\section{Actors in the Communication Network}

In a network, an actor is the main structure forming a network called a node. This node is identified and mapped to its relationships which ultimately form a network. In this study, the actors (nodes) were political elites who communicated and directly involved in the party coalitions for the 2019 Presidential Election. The names of actors in a network are called name generators.

From the analysis conducted on the main article of Tempo magazine, it turned out that not all parties joined the communication network. Following is the number and percentage of party members participating in the communication network for the formation of party coalitions:

Of the total $100 \%$ participation of the political elites in the network, some parties did not involve in communication at all in the main report of Tempo news magazine, January 15-21 to 9-15 July 2018 edition. The party was National Democrat, with $0 \%$ participation. Since the beginning of the 2019 presidential election planning, the party had declared its involvement in Jokowi's party coalition.

Table 2 Map of the Distribution of the Party Coalition

\begin{tabular}{ll}
\hline Presidential and Vice Presidential Candidates & Supporting Parties \\
\hline Prabowo Subianto and Sandiaga Salahuddin & - Demokrat \\
Uno & - PKS \\
& - Gerindra \\
& - PAN \\
Joko Widodo and Ma'ruf Amin & - PKB \\
& - PKPI \\
& - PDIP \\
& - Nasdem \\
& - Hanura \\
& - PPP \\
& - Golkar
\end{tabular}

Source: Author's personal research (2019) 


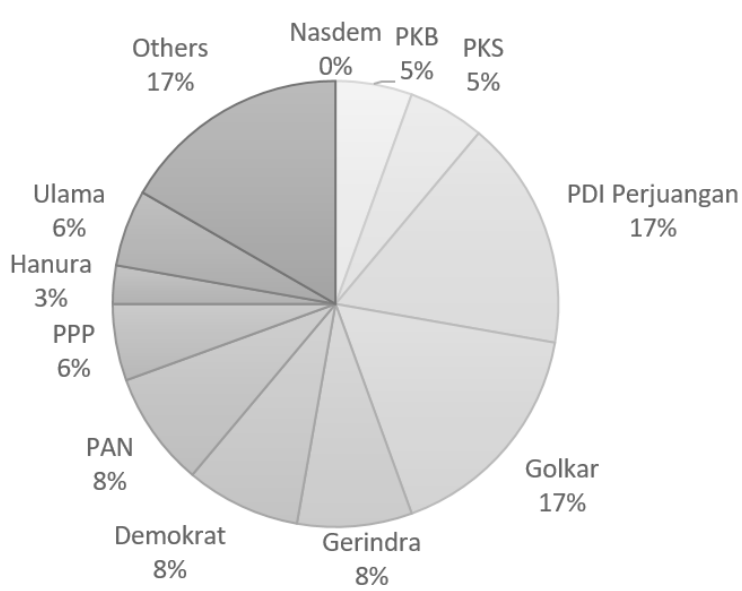

Figure 1. Percentage of party members' participation Source: Author's analysis result (2019)

\section{Complete Network Structure}

The network structure refers to the full picture of the network that involves all actors in the process of forming party coalitions in the 2019 Presidential Election. Following graphic is an overview of entire networks based on processed sociometric data:

Figure 2 shows the potential for concentration. Some actors were in the middle of the network, while others located on the edge of the network. The actors on the edge of this network were political elites who only had at least one relationship with other actors. They had difficulties in reaching other actors as it required several steps. However, the actors in the middle of the network acted as the center of communication. Building many relationships with other actors in the network motivated the placement of actors in the center. The possibility of actors in the middle of the network to reach other actors was higher than the actors on edge.

Analyzing the diameter and distance network data may prove an actor's ability to communicate with other actors. Diameter in the network is the farthest distance an actor can contact the other actor. The network above has a diameter of 8 which means that the furthest distance the actor can interact with each other is eight steps. Distance is the number of average steps needed by each actor to interact with each other. The actors in the middle of the network were easy to communicate as the distance was reasonably close. In this research, the actors in

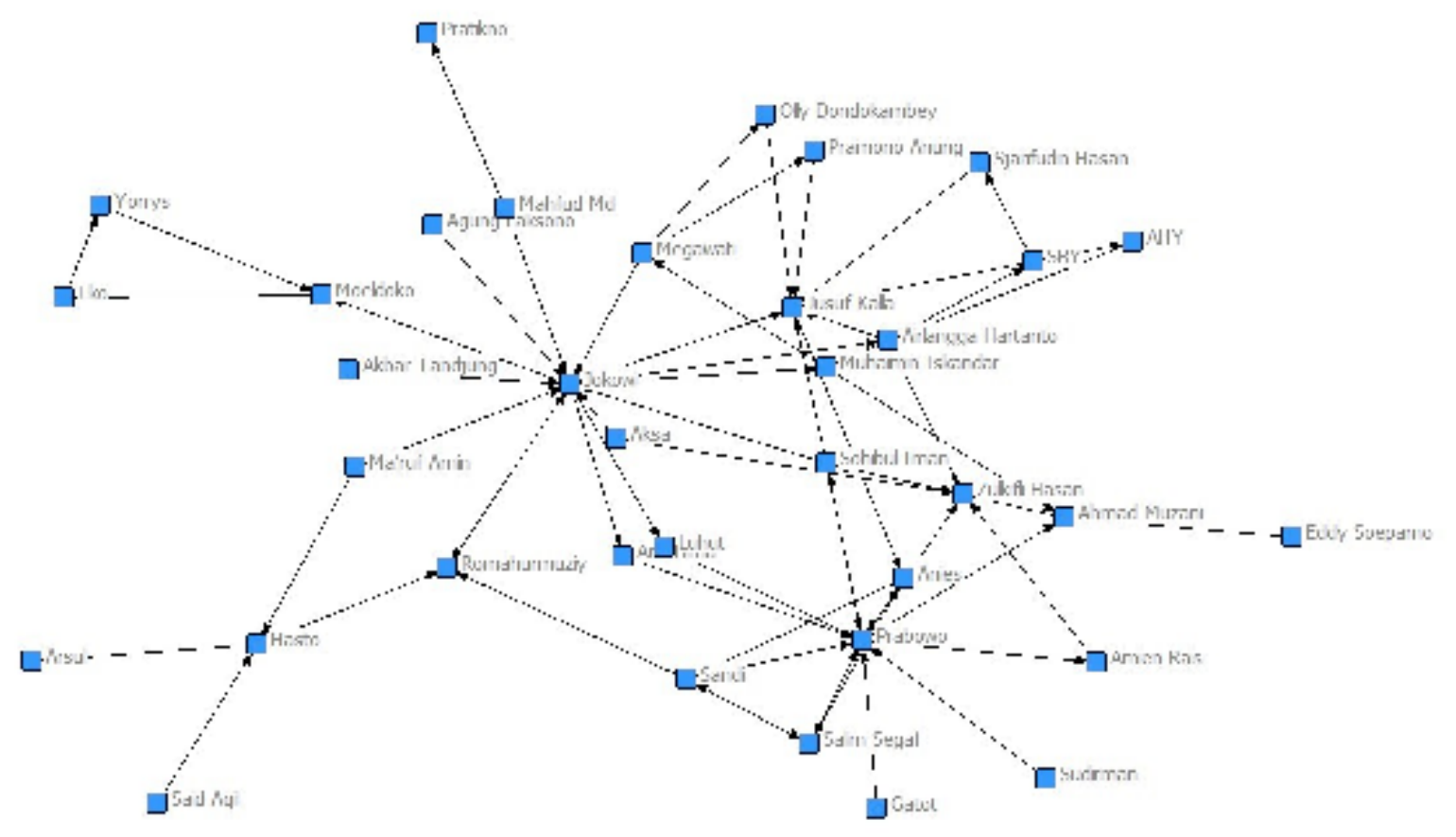

Figure 2. Sociogram of political elites' network

Source: Author's analysis result (2019) 
the middle were Jokowi and Prabowo. From the data mentioned above, Jokowi may contact Prabowo in two steps. It means that Jokowi only needed to pass one person as indicated by the sociogram. That person was Luhut who stand between Jokowi and Prabowo. This finding was evidence when Jokowi asked Luhut to meet Prabowo three days after the presidential election to cool down the heated political atmosphere three days after the presidential election.

It is possible that the middle actor reaches out to the edge actor, who can be closer than the edge actor with another edge actor. For example, Prabowo contacted Arsul Sani. In the sociogram graphic, Arsul was on the edge of the network while Prabowo was in the middle. In order for Prabowo to contact Arsul, Prabowo must go through four steps including SandiRomahurmuziy-Hasto-Arsul. This distance was still quite close, compared to the distance that the peripheral actors must take to be able to reach actors who were also on edge, such as Pratikno to Eddy Soeparno. In order for these two actors to communicate, the network must go through at least six steps, including Mahfud-Jokowi-Sohibul-Zulkifli-MuzaniEddy. Based on the reality illustrated by the sociogram graphic, the advantage of actors who were in the middle of the network was their ability to reach other actors more closely.

\section{Coalition Communication Network}

The 2019 Presidential Election had brought two coalitions of political parties to surface. An analysis of the patterns of personal networks from Jokowi and Prabowo as coalition leaders was examined to illustrate how the communication network of each coalition took place. Figure 3 is a graphic of the ego network of the two actors:

Figure 3 (left) of Jokowi's ego network showed that the communication of the coalition members (alter) only occurred with Jokowi (ego) as the center. This network was similar to a radial network where people around Jokowi did not interact with each other. The same case also occurred toward Prabowo's ego. Figure 3 (right) shows where alters around Prabowo did not interact with each other. The alters only communicated with Prabowo.

In sum, the networks of these two egos were radial networks where the majority of alters of each ego did not interact with each other. When political elites of party coalition did not communicate with each other adequately, the coalition found it challenging to become a robust political party coalition. When there were misunderstandings or differences of political opinion, the cohesiveness of the coalition could be affected and even led to division in the future. For example in Yudhoyono's second-

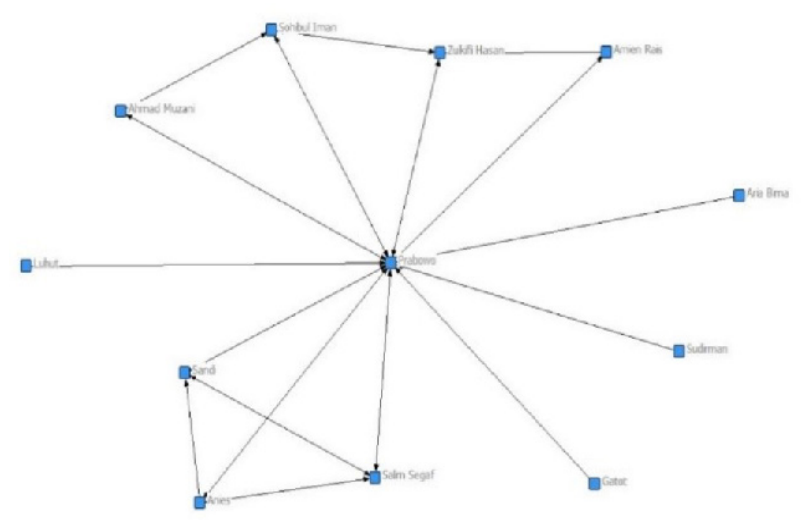

Figure 3. Jokowi's Network of Ego (left) and Prabowo's Network of Ego (right) Source: Author's analysis result (2019) 
period government in 2010, the party coalition began to crack even before the president's 100 days in office. The situation occurred due to differences of opinion regarding the Special Committee of the Century Bank Case.

\section{Click}

Based on Weick et al.'s network theory (2005) and Farace et al. 's introduction of the concept of communication and organizational network (1977), there were small groups that made up the bigger network. There were three clicks in this political elite communication network. They include: 1) Anies, Prabowo, Salim Segaf, and Sandiaga Uno; 2) Prabowo, Salim, password; and 3) Prabowo, Sohibul Iman, Zulkifli.

Based on the click data above, two clicks had three members while only one click had four members. There were no clicks formed by more than four political elites even though the coalition formed between the two coalitions was more than three political parties. It indicated that communication between political elites of party coalitions had not been robust. Usually, it was due to the necessity of longer time to unify the vision and direction of the coalition formed.

Prabowo, Anis, Salim Segaf and Sandiaga Uno played a role as click because a contract bound them. It was evident in the main report of Tempo Magazine as follow"In Jakarta, Anies and Sandiaga Uno are bound by a political contract to support Prabowo in the 2019 Election. Other points Anies may not advance as a candidate for President except Gerindra and PKS who carry him in the Jakarta regional election with other wishes. According to Fadli Zon, the draft agreement was made by him, "use this ballpoint pen," he said, pointing to a ballpoint pen in his shirt pocket. After the agreement letter, he intended to attach the stamp to the document. Anies-Sandi, Prabowo, and chairman of the PKS Shura assembly Salim Segaf Al-Jufri signed the letter" (Tempo News Magazine, 15-21/01/2018).
Meanwhile, the creation of click between Prabowo, Sohibul Iman and Zulkifli Hasan because Gerindra, PKS, and PAN agreed to a coalition in the 2019 Presidential Election. It is noteworthy that there was no click on Jokowi. The Jokowi coalition constructed from six parties (PDIP, Golkar, Nasdem, PKB, PPP, and Hanura) did not show any communication made by them together. The situation signified the absence of political communication among the political elites of the party coalition members.

Thus, when referring to the above click, it showed that Prabowo's political communication with his coalition partner was slightly better than the Jokowi coalition. It was also in line with the data on the ego/personal network density of the two actors, where the density of the Prabowo network was above the density of Jokowi.

This finding supported previous data regarding the nature of coalitions that were not well integrated. In other words, the network was open (radial). The formation of this coalition did not occur when all members jointly discuss cooperation plan; instead, the political elites formed a coalition by exploring the potential of cooperation from other political elites one by one. So that communication between them was limited to ego actors with their alters.

\section{Stars or Hubs}

Stars are individuals who become the center and communication path of most members of the network (Jaubah, 2013). The analysis of data that contains the value of the degree centrality may reveal political elites who act as stars. The value of the degree centrality shows how popular an actor compars to other actors. There are two types of degree centrality values. They are out-degree and in-degree. Out-degree describes how much an actor contacts other actors, while in-degree describes how many actors contact him. Table 3 shows the calculation data regarding the value of the centrality of the proximity of the actors: 
Table 3 Value of Degree Centrality

\begin{tabular}{|c|c|c|c|}
\hline \multirow{2}{*}{ Number } & \multirow{2}{*}{ Actors } & \multicolumn{2}{|c|}{ Degree Centrality } \\
\hline & & Out Degree & In Degree \\
\hline 1 & Agus H. Yudhoyono & 1 & 1 \\
\hline 2 & Agung Laksono & 1 & 0 \\
\hline 3 & Ahmad Muzani & 2 & 3 \\
\hline 4 & Airlangga Hartanto & 5 & 2 \\
\hline 5 & Akbar Tandjung & 1 & 0 \\
\hline 6 & Aksa Mahmud & 2 & 0 \\
\hline 7 & Amien Rais & 1 & 1 \\
\hline 8 & Anies Baswedan & 3 & 3 \\
\hline 9 & Aria Bima & 1 & 1 \\
\hline 10 & Arsul Sani & 0 & 1 \\
\hline 11 & Eddy Soeparno & 1 & 0 \\
\hline 12 & Eko Sulistyo & 1 & 1 \\
\hline 13 & Gatot Nurmantyo & 2 & 0 \\
\hline 14 & Hasto Kristiyanto & 2 & 2 \\
\hline 15 & Jokowi & 9 & 11 \\
\hline 16 & Jusuf Kalla & 1 & 8 \\
\hline 17 & Luhut Binsar Pandjaitan & 3 & 1 \\
\hline 18 & Mahfud MD & 2 & 0 \\
\hline 19 & Ma'ruf Amin & 2 & 1 \\
\hline 20 & Megawati Soekarno Putri & 3 & 1 \\
\hline 21 & Moeldoko & 1 & 2 \\
\hline 22 & Muhaimin Iskandar & 3 & 2 \\
\hline 23 & Olly Dondokambey & 1 & 1 \\
\hline 24 & Prabowo & 8 & 16 \\
\hline 25 & Pramono Anung & 1 & 1 \\
\hline 26 & Pratikno & 0 & 1 \\
\hline 27 & M. Romahurmuziy & 2 & 3 \\
\hline 28 & Susilo B. Yudhoyono & 3 & 1 \\
\hline 29 & Said Aqil Siroj & 1 & 0 \\
\hline 30 & Salim Segaf & 3 & 3 \\
\hline 31 & Sandiaga Uno & 3 & 3 \\
\hline 32 & Sjarifudin Hasan & 1 & 1 \\
\hline 33 & Sohibul Iman & 5 & 4 \\
\hline 34 & Sudirman & 1 & 0 \\
\hline 35 & Yorrys & 1 & 1 \\
\hline 36 & Zulkifli Hasan & 4 & 5 \\
\hline
\end{tabular}

Source: Author's personal research (2019)

Based on Tabel 3, the most in-degree actor was Prabowo with a value of 16 . In the second position was Jokowi with a value of 11. While the actor who most often contacted (out-degree) was Jokowi with a grade centrality value of 9, and in the next position was Prabowo with a value of 8 . These two actors, Jokowi and Prabowo, were candidates in the 2014 election and would return to compete in the 2019
Presidential Election. When this finding was related to sociogram of political elites' network, these two actors were in the middle of the network and became communication centers, meaning they also acted as stars in the network.

Referring to Jokowi's second highest indegree position, the reason that attracted the attention of other political elites to invite Jokowi to work together was Jokowi's electability, 
which was always above his challenger, Prabowo. On the other hand, Prabowo, who had the most significant in-degree value of centrality was Jokowi's only competitor. Thus, other political elites tried to explore the possibility of a coalition with Prabowo for various reasons. One of them was the desire to become Prabowo's vice-presidential candidate. Therefore, it was not surprising if Prabowo was an actor in the network who was most often contacted by other actors. As the presidential candidates in the 2019 election, it was common for Jokowi and Prabowo communicated with many political elites. The reason was to mobilize as much support as possible. The more support, the stronger their position would be and the possibility of becoming the winner of the election would be even higher.

\section{Cosmopolites}

Cosmopolites refer to individuals in a network that can relatively relate to all actors in the system. People who have a closeness to almost all actors posit cosmopolites or actors who connect their group with the environment (Hertanto, Sugiyanto, \& Safitri, 2016). Calculating the value of proximity of each actor is the way to identify

Table 4 Value of Closeness Centrality

\begin{tabular}{|c|c|c|}
\hline Number & Actor & Out Closeness Centrality \\
\hline 1 & Agus Harimurti Yudhoyono & 163 \\
\hline 2 & Agung Laksono & 153 \\
\hline 3 & Ahmad Muzani & 164 \\
\hline 4 & Airlangga Hartanto & 139 \\
\hline 5 & Akbar Tandjung & 153 \\
\hline 6 & Aksa Mahmud & 145 \\
\hline 7 & Amien Rais & 188 \\
\hline 8 & Anies Baswedan & 180 \\
\hline 9 & Aria Bima & 181 \\
\hline 10 & Arsul Sani & 315 \\
\hline 11 & Eddy Soeparno & 182 \\
\hline 12 & Eko Sulistyo & 300 \\
\hline 13 & Gatot Nurmantyo & 176 \\
\hline 14 & Hasto Kristiyanto & 179 \\
\hline 15 & Jokowi & 135 \\
\hline 16 & Jusuf Kalla & 203 \\
\hline 17 & Luhut Binsar Pandjaitan & 181 \\
\hline 18 & Mahfud MD & 145 \\
\hline 19 & Ma'ruf Amin & 156 \\
\hline 20 & Megawati Soekarno Putri & 153 \\
\hline 21 & Moeldoko & 300 \\
\hline 22 & Muhaimin Iskandar & 146 \\
\hline 23 & Olly Dondokambey & 222 \\
\hline 24 & Prabowo & 158 \\
\hline 25 & Pramono Anung & 222 \\
\hline 26 & Pratikno & 315 \\
\hline 27 & Muhammad Romahurmuziy & 160 \\
\hline 28 & Susilo Bambang Yudhoyono & 174 \\
\hline 29 & Said Aqil Siroj & 197 \\
\hline 30 & Salim Segaf & 180 \\
\hline 31 & Sandiaga Uno & 163 \\
\hline 32 & Sjarifudin Hasan & 222 \\
\hline 33 & Sohibul Iman & 145 \\
\hline 34 & Sudirman & 176 \\
\hline 35 & Yorrys & 300 \\
\hline 36 & Zulkifli Hasan & 164 \\
\hline
\end{tabular}

Source: Author's personal research (2019) 
cosmopolites. Closeness refers to how close the actor is to other actors. The following is the value of the centrality of closeness between actors:

Table 4 showed that the actor who had the best closeness value was Jokowi at 135 . When the party coalition exploration process, Jokowi also does not rule out any Party to approach, he even routinely meets with coalition party leaders since December 2017. The image of Jokowi who was famous for being "populist" supported Jokowi's position as a network cosmopolites. By the argument on the previous sociogram, that actors in the middle of the network have the advantage of reaching out to other actors in the network. It meant that middle-level actors could refer to as actors closest to other actors in the network.

\section{Bridges or cutpoints}

Actors acting as bridges are an important aspect of a communication network. The network will not form properly without bridges, and the actors who become bridges serve to connect one actor to another. Bridges are the connector between two clicks, and the individual is in one click (Utami, 2007).

Table 5 Value of Betweenness Centrality

\begin{tabular}{|c|c|c|}
\hline Number & Actor & Intermediary Centrality \\
\hline 1 & Agus Harimurti Yudhoyono & 16,5 \\
\hline 2 & Agung Laksono & 0,0 \\
\hline 3 & Ahmad Muzani & 34,4 \\
\hline 4 & Airlangga Hartanto & 135,0 \\
\hline 5 & Akbar Tandjung & 0,0 \\
\hline 6 & Aksa Mahmud & 0,0 \\
\hline 7 & Amien Rais & 0,0 \\
\hline 8 & Anies Baswedan & 111,0 \\
\hline 9 & Aria Bima & 16,9 \\
\hline 10 & Arsul Sani & 0,0 \\
\hline 11 & Eddy Soeparno & 0,0 \\
\hline 12 & Eko Sulistyo & 32,0 \\
\hline 13 & Gatot Nurmantyo & 0,0 \\
\hline 14 & Hasto Kristiyanto & 55,5 \\
\hline 15 & Jokowi & 523,2 \\
\hline 16 & Jusuf Kalla & 102,5 \\
\hline 17 & Luhut Binsar Pandjaitan & 16,9 \\
\hline 18 & Mahfud MD & 0,0 \\
\hline 19 & Ma'ruf Amin & 56,0 \\
\hline 20 & Megawati Soekarno Putri & 58,0 \\
\hline 21 & Moeldoko & 63,0 \\
\hline 22 & Muhaimin Iskandar & 99,2 \\
\hline 23 & Olly Dondokambey & 1,0 \\
\hline 24 & Prabowo & 245,8 \\
\hline 25 & Pramono Anung & 1,0 \\
\hline 26 & Pratikno & 0,0 \\
\hline 27 & M Romahurmuziy & 115,0 \\
\hline 28 & Susilo B Yudhoyono & 58,0 \\
\hline 29 & Said Aqil Siroj & 0,0 \\
\hline 30 & Salim Segaf & 0,5 \\
\hline 31 & Sandiaga Uno & 63,0 \\
\hline 32 & Sjarifudin Hasan & 0,0 \\
\hline 33 & Sohibul Iman & 215,3 \\
\hline 34 & Sudirman & 0,0 \\
\hline 35 & Yorrys & 1,0 \\
\hline 36 & Zulkifli Hasan & 41,7 \\
\hline
\end{tabular}

Source: Author's personal research (2019) 
This betweenness is not the same as popularity or closeness. An actor can have good popularity and closeness, but not necessarily to occupy a position as a bridge. Calculating the intermediary value of each actor enable to find bridges in a communication network between political elites.

Presidential candidates for the 2019 election, Jokowi and Prabowo, filled the best value of betweenness centrality. Besides being active in exploring the possibility of a coalition with other parties, it turned out they could also be bridges to bring together other parties. If connected with the sociogram graphic, both Jokowi and Prabowo were the connector in the communication network among the political elites in the formation of party coalitions for the 2019 Presidential Election. The elimination of the existence of these two political elites would break down the network.

According to Cheibub, two characters influenced the coalition model (Cheibub, 2007). The first character was vote seeking, where the reason for political elites in forming coalitions was to win the election. They were then open to anyone who wanted to join (catch-all). Analysis of the communication network found that political elites had to go through political communication with as many other actors as possible to consider the potential for the coalition. As a result, political elites from various parties tended to open themselves to anyone.

Both the Jokowi and Prabowo coalitions adopted this pattern of communication of the political elites without exception. It had an impact on the communication network of the political elites in the formation of party coalitions in the 2019 Presidential Election that were spread and not cohesive. Such networks indicated that one actor could not directly communicate with other actors. They had to go through an intermediary.

The second character mentioned by Cheibub was the effort of political actors to pursue political positions (office seeking) (Cheibub, 2007). This understanding argued that political parties in building coalitions wanted to increase opportunities in obtaining positions in the government cabinet._So that in choosing coalition partners, internal party maneuvers arouse to join potential candidates to win in the presidential election.

In line with this character in the case of the 2019 Presidential Election, the competition only occurred between two candidate pairs so that both still had the possibility of winning or losing. Alternatively, another interpretation was that both had the same potential before the election begun. Thus, political parties outside the two candidates made some calculations and considerations. There were two choices, whether to support the continuation of the government currently held by Jokowi or to form a new government model with Prabowo. The provision of political support certainly had expected rewards, none other than the matter of political position in the cabinet. For example, the Golkar party's political maneuvers that moved from the Prabowo coalition in the 2014 election to the Jokowi coalition in the 2019 election. Although Golkar stated that its support was unconditional support, Golkar's belief in being involved in the government if Jokowi to be re-elected showed the motive for seeking political positions behind this party's actions.

The facts above proved that in practice, the political coalitions were inseparable from political profit and loss considerations. The relations built among the political elites in building coalition were instrumental relation where relations created because there were similarity in needs. The presidential candidates had the interest to gather power while supporting parties had the interests to pursue political positions in the cabinet.

There were two coalitions of the 2019 Presidential Election. The strength of this coalition was inseparable from how the communication pattern built since the beginning of the formation. An integrated network became a character of a strong coalition. This integrated network interlocked where all members in the network interacted with each other (Rogers \& Kincaid, 1981). However, in this study, no 
interlock network was found. Jokowi's personal network (ego network) was radial, where communication of political elites who were part of this coalition centered on the main actor (Ego). Coalition members (Alter) did not communicate with each other. They only communicated with the head of the coalition (Ego). It was also the case with Prabowo's ego network. The Prabowo network was also radial, where communication centered on just one person, Prabowo who was the coalition leader. Thus it can be concluded that the coalitions were not well integrated, because coalition members did not have good relations.

From the perspective of the communication network, coalitions that were not well integrated were feared to have an impact on the cohesiveness of the coalition in the future. If there were differences of opinion, it would be challenging to solve the problem. It was because political communication between coalition members did not go well so it would be difficult to find solutions to problems. The coalition leaders determined the decision with the presidential candidates without involving partners who had already joined the team. If this pattern to be maintained, the strength of the coalition would be difficult to realize.

\section{Conclusion}

Networks are social arrangements created through communication between individuals and groups. One way to look at the organizational structure is to examine these interaction patterns to see who is communicating with whom. It is interesting to look at groups of communication relationships that are interconnected to form the entire network of organizations because no one communicates the same as all members of the organization. Within the context of political communication for the 2019 Presidential Election in Indonesia, analyzing communication network enabled to identify the role of political elites in forming a coalition to support presidential candidates.
The communication network of the political elites in the formation of the 2019 Presidential Election coalition showed that the practice of communication centered on certain political actors. The main political actors were Jokowi and Prabowo as candidates in the 2019 Presidential Election. The centralization of communication channels to Jokowi and Prabowo placed them in influential positions. They were actors who made decisions and flexibility in establishing communication with other actors in the network.

This study found that the formation of a coalition of political elites and parties was not only because of ideological similarities. However, it was also based on the existence of profit-loss considerations if particular political elites decided to the coalition, both in targeting positions and support to win the Presidential Election. Also, the experience of the relation of political elites also played an important role.

\section{References}

Adeni, S., \& Harahap, M. A. (2018). Komunikasi Politik dan Keterwakilan Perempuan dalam Arena Politik. Perspektif Komunikasi, 1(2). Retrieved from https://jurnal.umj. ac.id/ index.php/perspektif/article/view/2849 Ainiyah, N. (2017). Komunikasi Politik Perempuan. LISAN AL-HAL: Jurnal Pengembangan Pemikiran Dan Kebudayaan, 11(2), 307-330. https:// doi.org/10.35316/lisanalhal.v11i2.181 Cangara, H. (2009). Komunikasi Politik: Konsep, Teori, Dan Strategi. Jakarta: Rajawali Pers. Cheibub, J. A. (2007). Presidentialism, Parliamentarism, and Democracy. Cambridge: Cambridge University Press. Denton, R. E., \& Woodward, G. C. (1998). Political communication in America. Retrieved 25 April 2019, from https:// www.worldcat.org/title/political communication-in-america/ oclc/39217497 
Evelina, L. W., \& Angeline, M. (2015). Upaya Mengatasi Golput pada Pemilu 2014. Humaniora Binus, 6(1), 97-105. https:// doi.org/10.21512/humaniora.v6i1.3302

Farace, R. V., Monge, P. R., \& Russell, H. M. (1977). Communicating and organizing (Vol. 1077). Addison-Wesley Reading, MA. Hague, R., Harrop, M., \& McCormick, J. (2016). Comparative Government and Politics: an Introduction. Retrieved from http://public.eblib.com/choice/ publicfullrecord.aspx? $\quad \mathrm{p}=4763935$

Hertanto, D., Sugiyanto, S., \& Safitri, R. (2016). Analisis Struktur Jaringan Komunikasi dan Peran Aktor Dalam Penerapan Teknologi Budidaya Kentang (Petani Kentang Desa Ngantru Kecamatan Ngantang Kabupaten Malang). HABITAT, 27(2), 55-65. https:// doi.org/10.21776/ub.habitat.2016.027.2.7

Jaubah, A. M. (2013). Teori Jaringan Komunikasi. Retrieved 25 April 2019, from Scribd website: https://id.scribd.com/ doc/169314582/teori-jaringan-komunikasi

JK., S. (2017). Jaringan Komunikasi tentang Inovasi Obyek dan Strategi Kelompok Pengemis di Kampung Padangan di Kota Solo. Jurnal Ilmu Komunikasi, 15(2), 120133.Retrieved fromhttp://jurnal.upnyk.ac.id/ index.php/komunikasi/article/view/2160

Julianda, A. (2018). 'Parliamentary Threshold' dan Parpol Baru Peserta Pemilu. Retrieved 24 April 2019, from detiknews website: https://news.detik. com/kolom/d-3977292/parliamentarythreshold-dan-parpol-baru-peserta-pemilu

Lees, C. (2010). Coalition dynamics and the changing German party system. German Politics \& Society, 28(3), 119-132. https://doi.org/10.3167/gps.2010.280307

Littlejohn, S. W., \& Foss, K. A. (2010). Theories of Human Communication: Tenth Edition. Illinois: Waveland Press.
McNair, B. (2017). An Introduction to Political Communication. Retrieved 25 April 2019, from https://www.bookdepository.com/ Introduction-Political-CommunicationBrian-McNair/ 9780415739429 Monge, P. R., \& Contractor, N. S. (2003). Theories of Communication Networks. Oxford: Oxford University Press. Mulyana, D. (2013). Komunikasi politik, politik komunikasi: membedah visi dan gaya komunikasi praktisi politik (Cetakan pertama). Bandung: PT Remaja Rosdakarya.

Nimmo, D. (2019). Komunikasi Politik. Retrieved 25 April 2019, from https:// www.komunikasipraktis.com/2015/11/ pengertian-komunikasi-politik.html

Prokurat, S. (2014). Indonesian parliamentary and presidential elections in 2014. The electoral process and economic challenges. Retrieved 24 April 2019, from ResearchGate website: https://www.researchgate. net/publication/330909494_Indonesian_ parliamentary_and_presidential_ elections_in_2014_The_electoral_ process_and_economic_challenges Pujono, Muktiyo, M., \& Hastjarjo, S. (2015). Strategi Komunikasi Politik Calon Legislatif Partai Golkar dalam Memenangkan Pemilihan Umum 2014 di Kabupaten Sragen. Jurnal Ilmu Komunikasi, 13(3), 273-286. Retrieved from http://jurnal.upnyk.ac.id/ index.php/komunikasi/article/view/1465 Rogers, E. M., \& Kincaid, L. D. (1981). Communication networks: toward a new paradigm for research. Retrieved 25 April 2019, from https:// www.popline.org/node/400732 Roqib, M.(2008). Peran PolitikPerempuanDalam Kacamata Ict. Yinyang: Jurnal Studi Islam Gender Dan Anak, 3(1), 48-66. Retrieved from http://ejournal.iainpurwokerto. ac.id/index.php/yinyang/article/view/187 
Sambrook, R. J., \& Cushion, S. (2015). Election coverage: how the parties and leaders are faring on television. The Guardian, 2015. Retrieved from http:// www.theguardian. com/media/2015/apr/12/ election-coverage-tv-news-newspapers Sartori, G. (2005). Parties and Party Systems: A Framework for Analysis. London: ECPR Press.

Setiawan, B., \& Siregar, A. (1987). Metode Analisis Jaringan Komunikasi dan Analisis Isi. Yogyakarta: PAU Studi Sosial. Strata, T. (2016). Ambang Batas Parlemen (Parliamentary Threshold) dan Asas Demokrasi. Retrieved 24 April 2019, from http://repository.uksw. e d u / handle/123456789/11596

Sulaiman, A. I. (2010). Realitas Politikus Perempuan sebagai Komunikator Politik. Mimbar: Jurnal Sosial Dan Pembangunan, 26(1), 59-70. https:// doi.org/10.29313/mimbar.v26i1.292
Tiyanto, D., Pawito, Nilan, P., \& Hastjarjo, S. (2008). Perceptions of Indonesian Politics in the Run-up to the 2009 General Election. Asian Social Science, 4(11), 107-117. 10.5539/ass.v4n11p107

Utami,H.N.(2007).AnalisisJaringanKomunikasi untuk Menunjang Kegiatan Pemasaran pada Industri Kecil. Retrieved from https:// www.academia.edu/35744172/Analisis_ Jaringan_Komunikasi_Untuk_Menunjang_ Kegiatan_Pemasaran_Pada_Industri_Kecil Wahid, U. (2012). Aliansi Jaringan dalam Proses Komunikasi Politik Anggota Dewan Perwakilan Rakyat Daerah Perempuan. Jurnal Ilmu Komunikasi, 10(1), 69-84. Retrieved from http://jurnal.upnyk.ac.id/ index.php/komunikasi/article/view/87

Wasserman, S., Urbana-Champaign), S. (University of I. W., \& Faust, K. (1994). Social Network Analysis: Methods and Applications. Cambridge University Press. Weick,K.E.,Sutcliffe,K.M.,\&Obstfeld,D.(2005). Organizing and the Process of Sensemaking. Organization Science, 16(4), 409-421. https://doi.org/10.1287/orsc.1050.0133 